Louisiana State University

LSU Digital Commons

Faculty Publications

Department of Biological Sciences

$1-1-2014$

\title{
Two new species of Eimeria (Apicomplexa, Eimeriidae) from tree skinks, Prasinohaema spp. (Sauria: Scincidae), from Papua New Guinea
}

\author{
Chris T. McAllister \\ Eastern Oklahoma State College \\ Donald W. Duszynski \\ The University of New Mexico \\ Robert N. Fisher \\ United States Geological Survey \\ Christopher C. Austin \\ Louisiana State University
}

Follow this and additional works at: https://digitalcommons.Isu.edu/biosci_pubs

\footnotetext{
Recommended Citation

McAllister, C., Duszynski, D., Fisher, R., \& Austin, C. (2014). Two new species of Eimeria (Apicomplexa, Eimeriidae) from tree skinks, Prasinohaema spp. (Sauria: Scincidae), from Papua New Guinea. Acta Parasitologica, 59 (2), 263-266. https://doi.org/10.2478/s11686-014-0239-x
}

This Article is brought to you for free and open access by the Department of Biological Sciences at LSU Digital Commons. It has been accepted for inclusion in Faculty Publications by an authorized administrator of LSU Digital Commons. For more information, please contact ir@lsu.edu. 


\title{
Two new species of Eimeria (Apicomplexa, Eimeriidae) from tree skinks, Prasinohaema spp. (Sauria: Scincidae), from Papua New Guinea
}

\author{
Chris T. McAllister ${ }^{1 *}$, Donald W. Duszynski², Robert N. Fisher ${ }^{3}$ and Christopher C. Austin ${ }^{4}$ \\ ${ }^{1}$ Science and Mathematics Division, Eastern Oklahoma State College, Idabel, Oklahoma 74745, USA; \\ ${ }^{2}$ Department of Biology, University of New Mexico, Albuquerque, New Mexico 87131, USA; \\ ${ }^{3}$ U.S. Geological Survey, Western Ecological Research Center, 4165 Spruance Road, Suite 200, San Diego, California 92101-0812, USA; \\ ${ }^{4}$ Department of Biological Sciences and Museum of Natural Sciences, Louisiana State University, Baton Rouge, Louisiana 70803, USA
}

\begin{abstract}
Between September 1991 and June 1992, feces from 4 species of tree skinks, Prasinohaema spp. from Papua New Guinea, were collected and examined for coccidia. Two species, P. flavipes and $P$. prehensicauda were found to harbor eimerians which are described as new. Oocysts of Eimeria krausi sp. nov. from P. flavipes were ellipsoidal to subspheroidal with a smooth bilayered wall and measured $(\mathrm{L} \times \mathrm{W}) 19.2 \times 16.9 \mu \mathrm{m}$, with a length/width $(\mathrm{L} / \mathrm{W})$ ratio of 1.1 . Micropyle and oocyst residuum were absent but a fragmented polar granule was present. Sporocysts were ellipsoidal, $9.7 \times 6.7 \mu \mathrm{m}, \mathrm{L} / \mathrm{W}$ of 1.5. Stieda, subStieda and paraStieda bodies were absent. The sporocyst residuum was composed of many small granules in a compact mass between sporozoites. The sporozoites were sausage-shaped, $11.7 \times 2.7 \mu \mathrm{m}$, in situ, with an ellipsoidal posterior refractile body and a spheroidal anterior refractile body. Oocysts of Eimeria greeri sp. nov. from P. prehensicauda were ellipsoidal with a smooth bilayered wall, $(\mathrm{L} \times \mathrm{W}) 23.0 \times 18.3 \mu \mathrm{m}$, with a $\mathrm{L} / \mathrm{W}$ of 1.3. Micropyle and oocyst residuum were absent but a fragmented polar granule was present. Sporocysts were ellipsoidal, $9.7 \times 8.4 \mu \mathrm{m}$, with a L/W of 1.2. Stieda, subStieda and paraStieda bodies were absent. The sporocyst residuum was composed of many large granules in a compact mass between sporozoites. The sporozoites were sausage-shaped, with an ellipsoidal posterior refractile body and a spheroidal anterior refractile body. We document here the first report of coccidia from skinks of the genus Prasinohaema.
\end{abstract}

\section{Keywords}

Coccidia, Eimeria greeri sp. nov., Eimeria krausi sp. nov., Prasinohaema flavipes, Prasinohaema prehensicauda, Papua New Guinea, Sauria, Scincidae, tree skinks

\section{Introduction}

Skinks of the genus Prasinohaema are an interesting group of New Guinean lizards that possess green blood plasma, the result of the accumulation of the bile pigment biliverdin (Austin and Jessing 1994). There are 5 named species which are restricted to New Guinea, adjacent islands along its southeastern peninsula, and the Solomon Islands (Greer 1974; Mys 1988). One species, Prasinohaema flavipes (Parker) inhabits high elevations in the central ranges of New Guinea, and the Huon Peninsula, having been recorded at $1,400 \mathrm{~m}$ on the latter and at 2,000 $\mathrm{m}$ in the Finisterre Range (Mys 1988). Another species, Prasinohaema prehensicauda (Loveridge) is known to inhabit the montane regions of the central highlands of Papua New Guinea (PNG), but is presumably absent from Indonesian New Guinea (Loveridge 1945).
There is little known about the parasites from this group of lizards. Austin and Perkins (2006) and Perkins and Austin (2009) looked at their haemoparasites and hypothesized that the unusual physiology of these lizards might reduce or preclude their infection by blood parasites. Goldberg et al. (2010) provided the only study, to date, of their metazoan endoparasites. Here, we document 2 new species of Eimeria from the intestinal contents of Prasinohaema spp. from PNG.

\section{Materials and Methods}

Between September 1991 and June 1992, 4 species of Prasinohaema skinks $(n=14)$, including 4 yellow-footed greenblooded skink, P. flavipes, 6 prehensile green tree skink, P. prehensicauda, 2 Semon's green tree skink, P. semoni 
(Oudemans) and 2 green tree skink, P. virens (Peters) were collected by hand and fresh faeces from each was collected and placed in individual vials containing $2.5 \%(\mathrm{w} / \mathrm{v})$ aqueous potassium dichromate $\left(\mathrm{K}_{2} \mathrm{Cr}_{2} \mathrm{O}_{7}\right)$. Upon return to the laboratory, each sample was examined for coccidia by light microscopy after flotation in Sheather's sugar solution (specific gravity $=1.30$ ). Measurements were taken on 20 sporulated oocysts using a calibrated ocular micrometer and reported in micrometers $(\mu \mathrm{m})$ with means followed by the ranges in parentheses; photomicrographs were taken using Nomarski interference-contrast (NIC) optics. Oocysts were $\sim 60$ days old when measured and photographed. Descriptions of oocysts and sporocysts follow guidelines of Wilber et al. (1998) as follows: oocyst length (L) and width (W), their ranges and ratios (L/W), micropyle (M), oocyst residuum (OR), polar granules $(\mathrm{PG})$, sporocyst $(\mathrm{SP})$ length $(\mathrm{L})$ and width $(\mathrm{W})$, their ranges and ratio $(\mathrm{L} / \mathrm{W})$, sporocysts (SP), Stieda body (SB), sub-Stieda body (SSB), paraStieda body (PSB), sporocyst residuum (SR), sporozoites (SZ) anterior (ARB) and posterior (PRB) refractile bodies, and nucleus $(\mathrm{N})$. Voucher specimens of hosts were deposited in the Texas Natural History Collection (TNHC), Austin, Texas, USA. Photosyntypes of sporulated oocysts were accessioned into the United States National Parasite Collection (USNPC), Beltsville, Maryland. Lizard taxonomy follows the TIGR Reptile Database (Uetz and Hošek, 2013).

\section{Results}

One of $6(17 \%)$ P. flavipes and 1 of 4 (25\%) P. prehensicauda were each passing oocysts of undescribed species of Eimeria, which are described below as new; 2 P. virens and 2 P. semoni were negative.

Eimeria krausi sp. nov. (Figs 1-2, 4)

Description of sporulated oocyst: Oocyst shape: ellipsoidal to subspheroidal; colourless, smooth, bi-layered wall, $~ 1.4-1.6$ thick, inner 0.4-0.6, outer 0.8-1.0; L × W: $19.2 \times 16.9(17-24$ $\times 15-20), \mathrm{L} / \mathrm{W}: 1.1(1.0-1.2) ; \mathrm{M}, \mathrm{OR}$ absent, PG: present, but fragmented. Distinctive features of sporulated oocyst: Lack of $\mathrm{M}$ and OR, and sporocysts fill about $2 / 3$ to $3 / 4$ of space within the oocyst.

Description of sporocyst and sporozoites: SP shape: ellipsoidal, $\sim 0.5$ thick, with a smooth single-layered wall, $\mathrm{L} \times \mathrm{W}$ : $9.7 \times 6.7(9-11 \times 6-7), \mathrm{L} / \mathrm{W} 1.5(1.3-1.8) ; \mathrm{SB}, \mathrm{SSB}, \mathrm{PSB}$, all absent: SR: present as a compact spheroidal mass, $3.5(3-5)$ composed of many small granules between SZ; SZ: sausageshaped, $11.7 \times 2.7(10-13 \times 2-3)$ in situ, with ellipsoidal PRB, $3.0 \times 2.4(2-4 \times 2-3)$ and spheroidal ARB, $1.6(1-2)$; single $\mathrm{N}$ slightly posterior to midpoint of body. Distinctive features of sporocyst: lack of SB, SSB, PSB and the possible presence of a longitudinal suture that divides the SP into 2 walls.

Type host: Yellow-footed green-blooded skink, Prasinohaema flavipes (Parker, 1936) (Sauria: Scincidae); symbiotype host lost (Field Number CCA 0595) but others from same locality and date deposited in the TNHC 51882-4, 51958-65.

Type specimens: Photosyntype deposited as USNPC 107212.

Type locality: Kaironk Village, Madang Province, PNG ( $\left.8^{\circ} 14^{\prime} 15^{\prime \prime} \mathrm{S}, 144^{\circ} 28^{\prime} 50^{\prime \prime} \mathrm{E}\right)$, elevation 2,000 m.

Prevalence: 1/6 (17\%).

Sporulation: Unknown. Specimens were collected in the field, stored in $\mathrm{K}_{2} \mathrm{Cr}_{2} \mathrm{O}_{7}$ solution, and not examined until 60 days later.

Site of infection: Unknown. Oocysts were passed in faeces and host tissues were not collected or preserved for histological sectioning.

Etymology: The specific epithet is a patronym in honor of Dr. Fred Kraus, University of Michigan, Ann Arbor, Michigan, in recognition of his many contributions to the Papuan herpetofaunal literature.

Remarks: Sporulated oocysts of eimerians previously reported from skinks (see Modrý and Jirků 2006; McAllister et al. 2013b, c, d, in press) that are most similar in size to E. krausi include: Eimeria leiolopismatis Cannon, 1967 from the orange-tailed shadeskink, Saproscincus challengeri from Australia (Cannon, 1967) and Eimeria lipinia McAllister,
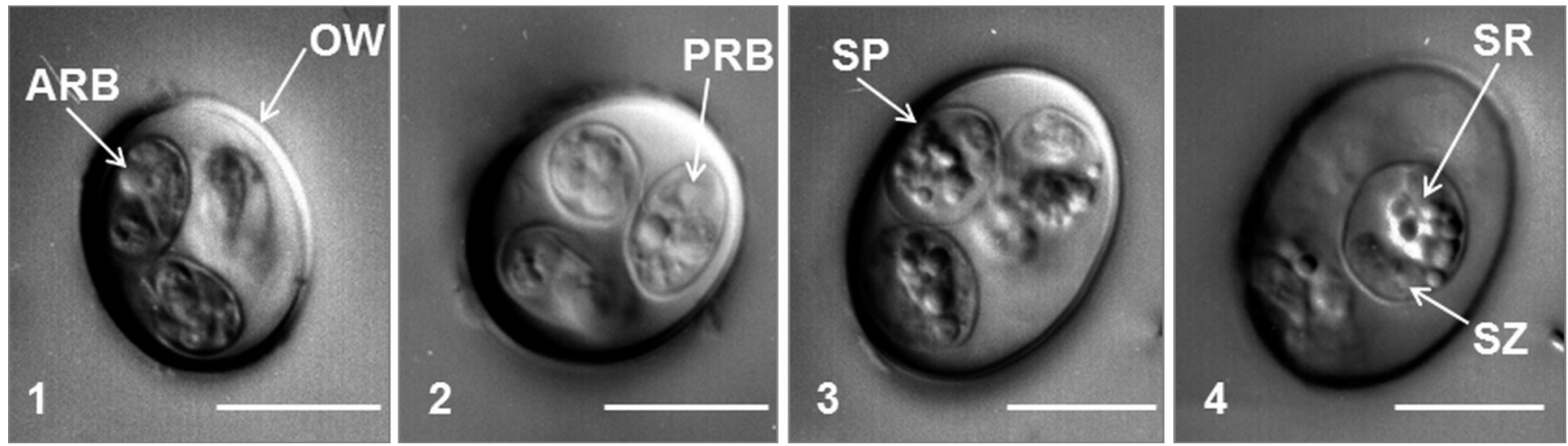

Figs 1-4. DIC photomicrographs of sporulated oocysts. 1-2. Eimeria krausi sp. nov. 3-4. Eimeria greeri sp. nov. Scale bars $=10 \mu \mathrm{m}$. Abbreviations: ARB (anterior refractile body); OW (oocyst wall); PRB (posterior refractile body); SP (sporocyst); SR (sporocyst residuum); SZ (sporozoite) 
Duszynski, Austin et Fisher, 2013 from the moth skink, Lipinia noctua from the Cook Islands, Fiji and PNG (McAllister et al. 2013c). However, sporulated oocysts of E. krausi can be differentiated from their oocysts as follows: oocysts of E. krausi are wider than E. leiolopismatis (16.9 [15-20] vs. $15.7[13-18])$ and, although oocysts of $E$. krausi are similar in size to E. lipinia $(19.2 \times 16.9[17-24 \times 15-20], \mathrm{L} / \mathrm{W}=1.1 v s$. $18.6 \times 16.9[15-22 \times 15-20], \mathrm{L} / \mathrm{W}=1.1$, see McAllister et al. $2013 \mathrm{c})$ as are their $\mathrm{SP}(9.7 \times 6.7[9-11 \times 6-7], \mathrm{L} / \mathrm{W}=1.5$ vs. $9.2 \times 6.8[8-11 \times 6-8], \mathrm{L} / \mathrm{W}=1.4$, respectively, the $\mathrm{SZ}$ of E. lipinia contain only a $\mathrm{PRB}$, whereas $E$. krausi $\mathrm{SZs}$ contains both PRB and ARBs. In addition to the host genus difference, behavioral, physiological and habitat differences between the hosts of these 3 forms suggest to us that they should be relegated to different species at this time. It appeared to us that there may be a suture in the SP wall, which could place E. krausi in another genus (Acroeimeria) except that species now placed into that genus are uniformly subspheroidal and undergo endogenous development epicytoplasmatically in the small intestine of infected hosts. Unfortunately, host tissues were not available for us to study; thus, until such material is available and/or until molecular evidence can suggest otherwise, we tentatively relegate this species to the genus Eimeria.

Eimeria greeri sp. nov. (Figs 3-4, 6)

Description of sporulated oocyst: Oocyst shape: ellipsoidal; colourless, smooth, bi-layered wall, $\sim 1.2-1.6$ thick, inner 0.4 0.6 , outer $0.8-1.0 ; \mathrm{L} \times \mathrm{W}: 23.0 \times 18.3(22-25 \times 17-20), \mathrm{L} / \mathrm{W}$ : 1.3 (1.1-1.4); M, OR absent, PG: present, but fragmented. Distinctive feature of oocyst: lack of $\mathrm{M}$ and OR, and sporocysts fill only about $50 \%$ of the space within the oocyst.

Description of sporocyst and sporozoites: SP shape: ellipsoidal to subspheroidal, $\sim 0.5$ thick, with a single-layered wall; $\mathrm{L} \times \mathrm{W}: 9.7 \times 8.4(9-11 \times 8-9), \mathrm{L} / \mathrm{W} 1.2(1.1-1.2) ; \mathrm{SB}, \mathrm{SSB}$, PSB, all absent: SR: present as a compact spheroidal mass composed of many small granules between SZ; SZ: (not measured) elongate with ellipsoidal PRB and spheroidal ARB; single $\mathrm{N}$ slightly posterior to midpoint of body. Distinctive features of sporocyst: lack of SB, SSB, PSB and the possible presence of a suture that divides the SP into 2 walls.

Type host: Prehensile green tree skink, Prasinohaema prehensicauda (Loveridge, 1945) (Sauria: Scincidae). Collected 2 October 1991. Symbiotype TNHC 51870 (field number CCA 0596).

Type specimens: Photosyntype deposited as USNPC 107213.

Type locality: Kaironk Village, Madang Province, PNG ( $\left.8^{\circ} 14^{\prime} 15^{\prime \prime} \mathrm{S}, 144^{\circ} 28^{\prime} 50^{\prime \prime} \mathrm{E}\right)$, elevation $2,000 \mathrm{~m}$.

Prevalence: $1 / 4(25 \%)$.

Sporulation: Unknown. Specimens were collected in the field, stored in $\mathrm{K}_{2} \mathrm{Cr}_{2} \mathrm{O}_{7}$ solution, and not examined until 60 days later.

Site of infection: Unknown. Oocysts were passed in faeces and host tissues were not collected or preserved for histological sectioning.

Etymology: The specific epithet is a patronym in honor of Dr. Allen E. Greer, Australian Museum, in recognition of his many contributions to New Guinea skink taxonomy.

Remarks: Oocysts of E. greeri are most similar to those of Eimeria nuiailan McAllister, Seville, Duszynski, Bush, Fisher et Austin, 2013 from emerald tree skinks, Lamprolepis smaragdina from PNG $(20.3 \times 18.3[22-25 \times 17-20]$, L/W $=$ 1.1 vs. $23.7 \times 19.1[21-26 \times 17-22], \mathrm{L} / \mathrm{W}=1.3$, McAllister et al. 2013d); however, SP of E. greeri are slightly smaller in length but larger in width with a significantly smaller L/W ratio $(9.7 \times 8.4[9-11 \times 8-9], \mathrm{L} / \mathrm{W}=1.2$ vs. $11.9 \times 7.0[10-14$ $\times 6-8], \mathrm{L} / \mathrm{W}=1.7)$. Just as in the previous description of E. krausi, there may be a suture in the SP walls of E. greeri, which also could place it in Acroeimeria; unfortunately, host tissues were not available for us to study; thus, until such material is available and/or until molecular evidence can suggest
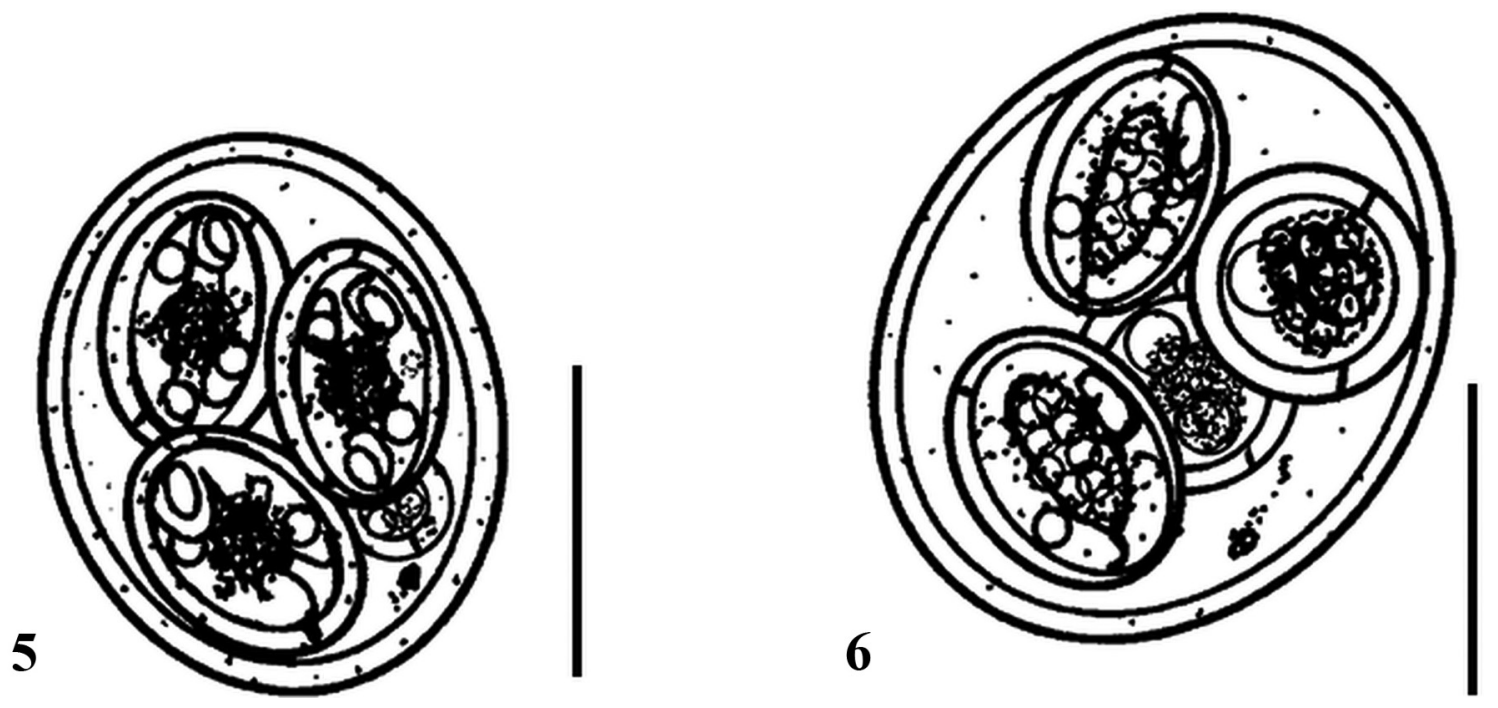

Figs 5-6. Composite line drawings of oocysts. 5. Eimeria krausi sp. nov. 6. Eimeria greeri sp. nov. Scale bars $=10 \mu \mathrm{m}$ 
otherwise, we tentatively also relegate this species to the genus Eimeria.

\section{Discussion}

The genus Prasinohaema is poorly known but is widespread in PNG, both in the lowlands and montane regions up to over 2,500 m; one lowland New Guinea species (P. virens) also occurs in the Solomon Islands. The species of this genus were described initially as a single entity, in part, due to the shared character of green blood (Greer 1974), but some of the species contain several other surprising characters for skinks such as adhesive "toe pads" (Irschick et al. 1996). All species in the genus are arboreal and, thus, are difficult to observe which may be why so little is known about their ecology and behavior. Two species, however, have color pattern sexual dimorphism (P. prehensicauda and $P$. virens) suggesting sexual selection is a force acting on the behavior in these 2 species (Kraus 2010). Very little is known about the parasite fauna of these green blooded lizards, and here we describe 2 new species of coccidia from this genus. Similar to other genera of southwest Pacific skinks recently surveyed (McAllister et al. 2013a, b, c, d, in press), these coccidia appear to be endemic to this genus. Both of these new Eimeria are most morphologically similar to species recently described from other arboreal genera of skinks, Lipinia and Lamprolepis, but until molecular studies can be done, we cannot make statements about their relationships. Further studies on coccidia within Prasinohaema and other genera in the southwest Pacific should continue to provide new species, and once more extensive surveys are completed, our understanding of the biogeography of these parasites will become clearer.

Acknowledgements. We thank the late Steve J. Upton (Kansas State University, Manhattan, Kansas, USA) for technical assistance, and Scott L. Gardner (Manter Parasite Collection, Lincoln, Nebraska, USA) for parasitological training of RNF. Further appreciation is extended to Patricia A. Pilitt (USNPC) for expert curatorial assistance. The PNG Department of Environment and Conservation supplied export permits to CCA for the lizard and parasite collections. This work was funded in part by IBN 9311139 and DEB 1146033 to CCA. The use of trade, product, or firm names in this publication does not imply endorsement by the U.S. Government.

\section{References}

Austin C.C., Jessing K.J. 1994. Green-blood pigmentation in lizards. Comparative Biochemistry and Physiology, 109A, 619-626.

Austin C.C., Perkins S.L. 2006. Parasites in a biodiversity hotspot: A survey of hematozoa and a molecular phylogenetic analysis of Plasmodium in New Guinea skinks. Journal of Parasitology, 92, 770-777.

Received: September 15, 2013

Revised: February 21, 2014

Accepted for publication: March 10, 2014
Goldberg S.R., Bursey C.R., Kraus F. 2010. Metazoan endoparasites of fourteen species of skinks (Squamata: Scincidae) from Papua New Guinea. Journal of Natural History, 44, 447-467.

Greer A.E. 1974. The generic relationships of the scincid lizard genus Leiolopisma and its relatives. Australian Journal of Zoology, Supplementary Series, No. 31, 1-67.

Irschick D.J., Austin C.C., Petren K., Fisher R.N., Losos J.B., Ellers O. 1996. A comparative analysis of clinging ability among pad-bearing lizards. Biological Journal of the Linnean Society, 59, 21-35.

Kraus F. 2010. Colour-pattern polymorphism in lizards of the genus Prasinohaema (Squamata: Scincidae). Herpetofauna, 40, 30-36.

Loveridge A. 1945. New scincid lizards of the genera Tropidophorus and Lygosoma from New Guinea. Proceedings of the Biological Society of Washington, 58, 47-52.

McAllister C.T., Duszynski D.W., Fisher R.N. 2013a. Two new species of Isospora (Apicomplexa: Eimeriidae) from skinks, Emoia spp. (Sauria: Scincidae) from Fiji and Papua New Guinea. Journal of Parasitology, 99, 677-679.

McAllister C.T., Duszynski D.W., Fisher R.N., Austin C.C. 2013 b. A new species of Eimeria Schneider, 1875 (Apicomplexa: Eimeriidae) from Carlia spp. (Sauria: Scincidae) from Papua New Guinea. Systematic Parasitology, 86, 53-57.

McAllister C.T., Duszynski D.W., Fisher R.N., Austin C.C. 2014 Four new species of coccidian (Apicomplexa: Eimeriidae) from Owen Stanley skinks, Papuascincus stanleyanus (Sauria: Scincidae), from Papua New Guinea. Folia Parasitologica, 61, in press.

McAllister C.T., Duszynski D.W., Austin C.C., Fisher R.N. 2013c. Three new species of coccidia (Apicomplexa: Eimeriidae) from skinks, Lipinia spp. (Sauria: Scincidae), from Oceania. Journal of Parasitology, 99, 1086-1088.

McAllister C.T., Seville R.S., Duszynski D.W., Bush S.E., Fisher R.N., Austin C.C. 2013d. Two new species of Eimeria Schneider, 1875 (Apicomplexa: Eimeriidae) from emerald tree skinks, Lampropeltis smaragdina (Sauria: Scincidae) from Papua New Guinea and the Philippines. Systematic Parasitology, 86, 165-171. DOI:10.1007/s11230-013-9442-7.

Modrý D., Jirků M. 2006. Three new species of coccidia (Apicomplexa: Eimeriorina) from the marble-throated skink, Marmorosphax tricolor Bavay, 1869 (Reptilia: Scincidae), endemic to New Caledonia with a taxonomic revision of Eimeria spp. from scincid hosts. Parasitology Research, 99, 416-428.

Mys B. 1988. The zoogeography of the scincid lizards from North Papua New Guinea (Reptilia: Scincidae). I. The distribution of the species. Bulletin de l'Institut Royal des Sciences Naturelles de Belgique: Biologie, 58, 127-183.

Perkins S.L., Austin C.C. 2009. Four new species of Plasmodium from New Guinea skinks: Integrating morphology and molecules. Journal of Parasitology, 95, 424-433.

Uetz P., Hošek J. 2013. The reptile database. http://www.reptiledatabase.org/. (Accessed 30 August 2013).

Wilber P.G., Duszynski D.W., Upton S.J., Seville R.S., Corliss J.O. 1998. A revision of the taxonomy and nomenclature of the Eimeria spp. (Apicomplexa: Eimeriidae) from rodents in the Tribe Marmotini (Sciuridae). Systematic Parasitology, 39, 113-135. 